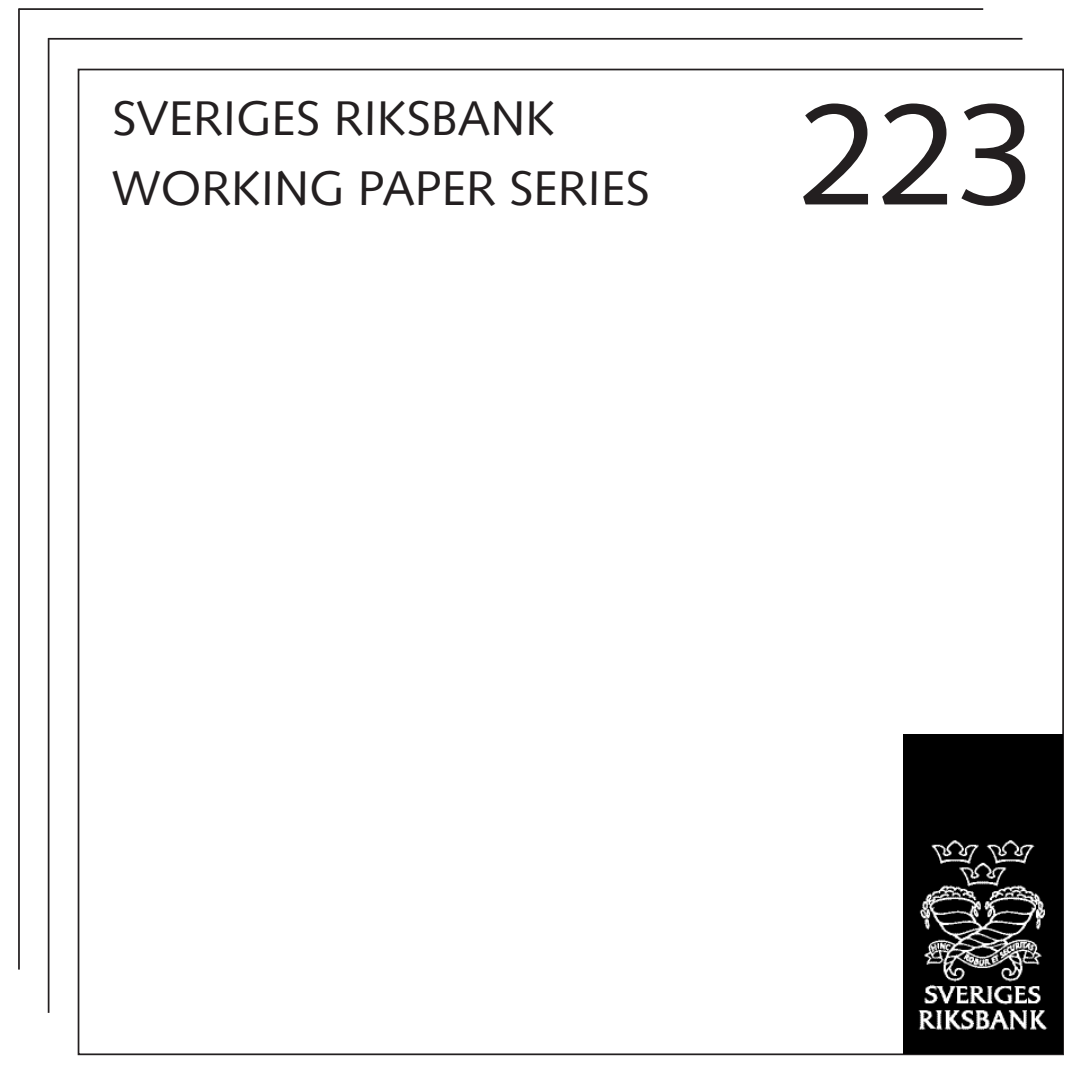

How Important are

Financial Frictions in the U.S. and the Euro Area

Virginia Queijo von Heideken

MAY 2008 
WORKING PAPERS ARE OBTAINABLE FROM

Sveriges Riksbank • Information Riksbank • SE-103 37 Stockholm Fax international: +4687870526

Telephone international: +4687870100

E-mail: info@riksbank.se

The Working Paper series presents reports on matters in the sphere of activities of the Riksbank that are considered to be of interest to a wider public.

The papers are to be regarded as reports on ongoing studies and the authors will be pleased to receive comments.

The views expressed in Working Papers are solely the responsibility of the authors and should not to be interpreted as reflecting the views of the Executive Board of Sveriges Riksbank. 


\title{
How Important are Financial Frictions in the U.S. and the Euro Area?*
}

\author{
Virginia Queijo von Heideken ${ }^{\dagger}$ \\ Sveriges Riksbank Working Paper Series
}

No. 223

May 2008

\begin{abstract}
This paper aims to evaluate if frictions in credit markets are important for business cycles in the U.S. and the Euro area. For this purpose, I modify the DSGE financial accelerator model developed by Bernanke, Gertler and Gilchrist (1999) by adding frictions such as price indexation to past inflation, sticky wages, consumption habits and variable capital utilization. When I estimate the model with Bayesian methods, I find that financial frictions are relevant in both areas. According to the posterior odds ratio, the data clearly favors the model with financial frictions both in the U.S. and the Euro area. Moreover, consistent with common perceptions, financial frictions are larger in the Euro area.
\end{abstract}

Keywords: Financial frictions, DSGE models, Bayesian estimation JEL: C11, C15, E32, E40, E50, G10

*I am indebted to Jesper Lindé and Torsten Persson for invaluable advice. I have also benefited from very useful comments from Fabio Canova, Giovanni Favara, Daria Finocchiaro, Sune Karlsson, Stefano Neri, Chris Sims, Lars E.O. Svensson, Mattias Villani, Karl Walentin, participants at the Society of Computational Economics conference 2005, CEPR-Bank of Finland conference 2006, and seminar participants at Uppsala University, the Swedish Central Bank and Bank of Spain. Thanks to Christina Lönnblad for editorial assistance. All remaining errors are mine. Financial support from Handelsbanken's Research Foundations is gratefully acknowledged. The views expressed in this paper are solely the responsibility of the author and should not be interpreted as reflecting the views of the Executive Board of Sveriges Riksbank.

${ }^{\dagger}$ Research Division, Sveriges Riksbank, SE-103 37 Stockholm, Sweden. E-mail: virginia.queijo.von.heideken@riksbank.se. 


\section{Introduction}

The works of Bernanke and Gertler (1989) and Carlstrom and Fuerst (1997), where endogenous procyclical movements in entrepreneurial net worth magnify investment and output fluctuations, constitute the corner stone of many recent theoretical papers with financial frictions. Bernanke, Gertler, and Gilchrist (1996) develop the so-called financial accelerator, a mechanism based on information asymmetries between lenders and entrepreneurs that creates inefficiencies in financial markets, which affect the supply of credit and amplify business cycles. Specifically, during booms (recessions), an increase (fall) in borrowers' net worth decreases (increases) their cost of obtaining external funds, further stimulating (reducing) investment and amplifying the effects of the initial shock. The financial accelerator approach has become wide-spread in the literature and many studies have introduced this type of frictions in DSGE models (Bernanke, Gertler, and Gilchrist (1999), henceforth BGG; Christiano, Motto, and Rostagno (2003)).

The purpose of this paper is to answer two questions. First, I want to determine if frictions in credit markets are important for business cycles, even if realistic frictions in goods and labor markets are added to a model with frictions in financial markets. After the banking crisis experienced by many countries in the 1990s, financial market conditions have turned out to be a relevant factor for economic fluctuations. In this paper, however, I do not consider financial frictions as a source of shocks, but as a mechanism for the propagation of other shocks in the economy. The second question I investigate is whether financial frictions have a similar magnitude in the U.S. and the Euro area. There is a common perception that financial markets are more developed in the U.S. and, consequently, more efficient. This is a relevant question for better understanding the relative performance of the two areas in recent years.

To answer these two questions, I modify the standard BGG model and estimate it for U.S. and European data using Bayesian methods. I extend the BGG model by adding price indexation to past inflation, sticky wages, consumption habits and variable capital utilization. One benefit of using Bayesian methods is that we can include prior information about the parameters, especially information about structural parameters from microeconomic studies. 
Despite the ample theoretical work based on the financial accelerator, more work is needed to evaluate the empirical relevance of this class of models. Christiano, Motto, and Rostagno (2003) estimate a DSGE model with a financial accelerator, but they fix the parameters related to the financial frictions and use the same calibration as in BGG. They ask which shocks had a more important role in the Great Depression and if a different monetary policy could have moderated the crisis. Christensen and Dib (2007) estimate the standard BGG model for the U.S. using maximum likelihood and find evidence in favor of the financial accelerator model. Meier and Muller (2006) also estimate a model with a financial accelerator for the U.S. but matching the impulse response functions after a monetary policy shock. They find that financial frictions do not play a very important role in the model. The results in my paper are able to reconcile the different conclusions of the previous literature. Moreover, while in the last two papers financial frictions are reduced to the elasticity of the external finance premium with respect to the change in the leverage position of entrepreneurs, in my paper I estimate the structural parameters affecting credit markets. In addition, Levin, Natalucci, and Zakrajsek (2004) use microdata to estimate the structural parameters of a canonical debt contract model with informational frictions. Using data for 900 U.S. firms over the period 1997Q1 to 2003Q3, they reject the null hypothesis of frictionless financial markets.

The paper contributes to the existing literature in three respects. It empirically investigates the importance of frictions in credit markets for business cycles both in the U.S. and the Euro area. It uses Bayesian methods to estimates a DSGE model with a financial accelerator. And unlike Christensen and Dib (2007) and Meier and Muller (2006), it can identify the structural parameters of the financial contract.

The results indicate that financial frictions are relevant in both areas. Using posterior odds ratios as the evaluation criterion, I find that the data favors a model with financial frictions both in the U.S. and the Euro area. Moreover, consistent with common perceptions, financial frictions are quantitatively more important in the Euro area.

The rest of the paper is organized as follows. In Section 2, I describe the model. Section 3 presents the estimation methodology while Section 4 presents the results. In Section 5, I discuss the results. Section 6 concludes. 


\section{The Model}

The specification of the model follows the work of BGG who incorporate financial market frictions through a financial accelerator mechanism in a general equilibrium model. The basic idea of the financial accelerator is that there exists a negative relationship between the external financial premium (the difference between the cost of funds raised externally and the opportunity cost of funds) and the net worth of potential borrowers. The intuition is that firms with higher leverage (lower net worth to capital ratio) will have a greater probability of defaulting and will therefore have to pay a higher premium. Since net worth is procyclical (because of the procyclicality of profits and asset prices), the external finance premium becomes countercyclical and amplifies business cycles through an accelerator effect on investment, production and spending.

Following the recent literature in DSGE models, I extend the basic model of BGG with other features proved to be important to match the data. These include external habit formation in consumption, variable capital utilization and Calvo prices and wages with full indexation to previous period inflation. It is important to introduce these frictions since when testing for financial frictions, the results might be capturing dynamics in the data caused by other frictions. For instance, for given parameters, the response of prices will be smoother in a model with a financial accelerator. However, introducing variable capital utilization also helps offset the fluctuations in labor productivity and affects the marginal cost, which is reflected in a more gradual response of prices. Given these additional frictions in other markets, I ask whether financial frictions are still empirically important.

Christiano, Motto, and Rostagno (2003) also extend the BGG model but with several differences. First, they include a banking sector. Second, in their paper, the return on deposits received by households is in nominal terms which allows for a "debt deflation" effect. Third, they assume there are costs for changing the investment flow while I assume there are adjustment costs in the production of capital. ${ }^{1}$ Fourth, in my model, variable capital utilization arises because of higher depreciation rates, while in their model high capital utilization gives rise to higher cost in terms of goods. Last, I introduce external

\footnotetext{
1 Groth and Khan (2007) find that it is difficult to motivate investment adjustment costs from a disaggregated empirical perspective.
} 
habit formation in consumption, while they use internal habits.

There are seven type of agents in the model: households, retailers, wholesale sector firms, capital producers, entrepreneurs, financial intermediaries and government. The following subsections describe the behavior of these agents.

\subsection{Households}

Consider a continuum of individuals, indexed by $j$, whose total mass is normalized to unity. In each period, each of these households maximizes its expected lifetime utility choosing a final consumption good, $c_{t}^{j}$, nominal bonds issued by the government, $n b_{t+1}^{j}$, and real deposits held at financial intermediates, $d_{t+1}^{j}$, which pay a real gross free risk rate $r_{t}$. Moreover, each household supplies differentiated labor services to the wholesale sector, $l_{t}^{j}$. Following Christiano, Eichenbaum, and Evans (2005), I assume that households buy securities with payoffs contingent on whether they can reoptimize their wages. This ensures that, in equilibrium, households are homogenous in consumption and asset holdings. Households discount the future at a rate $\beta$.

The representative household's period utility and budget constraint are

$$
U_{t}=\nu_{t}\left[\frac{1}{1-\sigma}\left(c_{t}^{j}-h c_{t-1}\right)^{1-\sigma}-\frac{\xi_{t}}{2}\left(l_{t}^{j}\right)^{2}\right]
$$

and

$$
\frac{n b_{t+1}^{j}}{p_{t}}+d_{t+1}^{j}+c_{t}^{j}=\frac{w_{t}^{j}}{p_{t}} l_{t}^{j}+r_{t-1} d_{t}^{j}+r_{t-1}^{n} \frac{n b_{t}^{j}}{p_{t}}-t_{t}+d i v_{t}+X_{t}^{j},
$$

where $w_{t}^{j}$ is the nominal wage of household $j, p_{t}$ is the nominal level of prices, $c_{t}$ is aggregate consumption, $t_{t}$ are lump-sum taxes, div $v_{t}$ are dividends received from ownership of firms and $X_{t}^{j}$ are net cash inflows from participating in state-contingent security markets. $\nu_{t}$ and $\xi_{t}$ are shocks to consumer preferences for intertemporal consumption and leisure, respectively, which follow $A R(1)$ processes with mean equal to one.

The introduction of external habit formation in consumption mainly helps account for the gradual and hump-shaped response of consumption observed in the data after a monetary policy shock.

Households also act as monopolistically competitive suppliers of differentiated labor services to the wholesale sector, where the labor aggregator has the Dixit-Stiglitz form 
and $\tau_{t}$ is a wage (net) mark up iid shock with mean $\tau$. I assume that households can reset their wages with probability $(1-\vartheta)$ at each period. Whenever the household is not allowed to reset its wage contract, wages are set at $w_{t}^{j}=\pi_{t-1} w_{t-1}^{j}$, where $\pi_{t-1}$ is gross inflation in the previous period. The first-order condition with respect to wages is

$$
\begin{aligned}
& E_{t} \sum_{k=0}^{\infty}(\beta \vartheta)^{k} \nu_{t+k}\left(c_{t+k}^{j}-h c_{t-1+k}\right)^{-\sigma}\left(\frac{\widehat{w}_{t}^{j}}{p_{t+k}} l_{t+k}^{j}\left[\frac{1}{\tau_{t+k}}\right]\right) \\
= & E_{t} \sum_{k=0}^{\infty}(\beta \vartheta)^{k} \nu_{t+k} \xi_{t+k}\left(l_{t+k}^{j}\right)^{2}\left[\frac{\left(\tau_{t+k}+1\right)}{\tau_{t+k}}\right] .
\end{aligned}
$$

\subsection{Retailers}

Firms in the final good sector produce a consumption good, $y_{t}$, in a perfectly competitive market, combining a range of intermediate goods, $y_{t}^{s}, s \in(0,1)$. The production function transforming intermediate goods into final output is the usual Dixit-Stiglitz aggregator where $\lambda_{t} \geq 0$ is a (net) mark up iid shock with mean $\lambda$. Firms take prices as given and choose $y_{t}^{s}$ to minimize costs subject to the Dixit-Stiglitz aggregator. The first-order conditions of this problem imply

$$
y_{t}^{s}=\left(\frac{p_{t}}{p_{t}^{s}}\right)^{\left(\lambda_{t}+1\right) / \lambda_{t}} y_{t} .
$$

\subsection{Wholesale Sector Firms}

The existing range of intermediate inputs are produced by a continuum of monopolistically competitive firms indexed by $s \in[0,1]$. Each firm hires the services of capital, $k_{t}^{s}$, and labor, $L_{t}^{s}$, to face the demand curve for its product. It rents capital from an entrepreneurial sector, which owns the capital stock.

Firms produce according to Cobb-Douglas production function:

$$
y_{t}^{s}=a_{t}\left(k_{t}^{s}\right)^{\alpha}\left(L_{t}^{s}\right)^{1-\alpha}
$$

where $a_{t}$ is a productivity shock which follows a first-order autoregressive process with mean one. Each intermediate goods firm chooses capital and labor to minimize its total costs, taking factor prices as given:

$$
\min _{L_{t}^{s}, k_{t}^{s}} \frac{w_{t}}{p_{t}} L_{t}^{s}+z_{t} k_{t}^{s}
$$


subject to the production function, where $z_{t}$ is the real rental price of capital.

Moreover, wholesale firms have market power and can choose prices to maximize expected profits with probability $1-\theta$ in each period (Calvo, 1983). Firms that cannot choose prices index their prices according to the last period's inflation rate: $p_{t}^{s}=\pi_{t-1} p_{t-1}^{s}$. For those firms that can choose prices, $\widehat{p}_{t}$, the first-order condition is

$$
\begin{aligned}
& E_{t} \sum_{k=0}^{\infty}(\beta \theta)^{k} m_{t, t+k} y_{t+k}\left(1 / \lambda_{t+k}\right)\left[\frac{\widehat{p}_{t}}{p_{t-1} \pi_{t+k}}\right]^{-1 / \lambda_{t+k}} \\
= & E_{t} \sum_{k=0}^{\infty}(\beta \theta)^{k} m_{t, t+k} y_{t+k}\left(\lambda_{t+k}+1\right) / \lambda_{t+k} s_{t+k}\left[\frac{\widehat{p}_{t}}{p_{t-1} \pi_{t+k}}\right]^{-\left(\lambda_{t+k}+1\right) / \lambda_{t+k}},
\end{aligned}
$$

where $\beta^{k} m_{t, t+k}=\beta^{k} \frac{u_{c}(t+k)}{u_{c}(t)}$ is the stochastic discount factor between periods $t$ and $t+k$ and $s_{t}$ is the real marginal cost. Profits are distributed to households.

\subsection{Capital Producers}

The physical stock of capital, $\widetilde{k}_{t}$ (where the $t$ subscript indicates when capital is actually used), is produced by a continuum of competitive firms indexed by $j$. At the end of each period, these firms produce new capital goods combining investment $i_{t}^{j}$ and the existing capital stock. Capital producers buy the undepreciated capital stock at the end of each period and after producing the new capital, they sell it back to the entrepreneurs at a relative price $q_{t}{ }^{2} \mathrm{I}$ assume there are increasing marginal adjustment costs in the production of capital: investment expenditures, $i_{t}^{j}$, deliver $\Phi\left(\frac{i_{t}^{j}}{\widetilde{k}_{t}^{j}}\right) \widetilde{k}_{t}^{j}$ new capital goods. This generates a weaker response of investment to any shock and a price of capital relative to consumption goods different from one.

I assume that investment decisions are made one period in advance, while the price of capital adjusts immediately after a shock. This assumption helps account for a gradual response of investment to shocks affecting the real interest rate, a strong feature observed in the data. Capital producers solve the following problem:

$$
\max _{i_{t+1}^{j}} E_{t}\left[q_{t+1} \Phi\left(\frac{i_{t+1}^{j}}{\widetilde{k}_{t+1}^{j}}\right) \widetilde{k}_{t+1}^{j}-i_{t+1}^{j}\right],
$$

where near the steady state $\Phi>0, \Phi^{\prime}()>0,. \Phi^{\prime \prime}()<$.0 . I also assume that in steady state, the relative price of capital is one. In the empirical part, I estimate $\varphi$, the elasticity

\footnotetext{
2 We can assume that capital-producing firms are owned by entrepreneurs. After entrepreneurs repurchase the old stock of capital, used capital depreciates.
} 
of the price of capital with respect to the investment-capital ratio in the steady state: $\varphi=\Phi^{\prime \prime}\left(\frac{i}{k}\right)\left(\frac{i}{k}\right)$.

The law of motion of the aggregate capital stock is

$$
\widetilde{k}_{t+1}=\Phi\left(\frac{i_{t}}{\widetilde{k}_{t}}\right) \widetilde{k}_{t}+\left(1-\delta\left(u_{t}\right)\right) \widetilde{k}_{t}
$$

where $u_{t}$ is the rate of capital utilization, $\delta\left(u_{t}\right) \in(0,1)$ is a convex depreciation function with $\delta^{\prime}()>$.0 , and $\delta^{\prime \prime}()>$.0 around the steady state. I choose the function $\delta\left(u_{t}\right)$ such that $\delta(0)=0, \delta(\infty)=1$ and in steady state, $\delta(1)=\delta$.

\subsection{Entrepreneurs and Financial Intermediaries}

Entrepreneurs own the physical stock of capital, $\widetilde{k}_{t}$, and provide capital services, $k_{t}$. They finance capital purchases both with their own net worth and debt. Capital services are related to the physical stock of capital by

$$
k_{t}=u_{t} \widetilde{k}_{t} .
$$

Entrepreneurs are risk neutral and have finite horizons: $\gamma<1$ is their probability of survival to the next period. This assumption rules out the possibility of entrepreneurs accumulating enough wealth to be fully self-financed: part of their capital must be financed through bank loans with a standard debt contract.

At the end of period $t$, entrepreneurs decide how much to borrow. Then, at the beginning of period $t+1$, after observing all the shocks, they choose how intensely to use their capital.

\subsubsection{Optimal Contract}

As in BGG, the return on capital depends on both aggregate and idiosyncratic shocks. The ex-post return on capital for entrepreneur $i$ is $\omega_{t+1}^{i} r_{t+1}^{k}$, where $\omega^{i}$ is an i.i.d. $\log$ normal random variable with pdf $F(\omega)$ and mean one. ${ }^{3}$ The riskiness of entrepreneurs is determined by the variance of the idiosyncratic shock, $\sigma_{\omega}$. The average return of capital

\footnotetext{
${ }^{3}$ As in Christiano, Motto, and Rostagno (2003), I assume that after entrepreneurs have purchased capital, they draw an idiosyncratic shock which changes their effective capital stock from $\widetilde{k}_{t+1}^{i}$ to $\omega_{t+1}^{i} \widetilde{k}_{t+1}^{i}$.
} 
in the economy is

$$
r_{t+1}^{k}=\frac{u_{t+1} z_{t+1}+\left(1-\delta\left(u_{t+1}\right)\right) q_{t+1}}{q_{t}}
$$

Entrepreneurs finance their capital stock at the end of period $t$ with their own net worth at the end of the period, $n_{t+1}^{i}$, and banks loans, $b_{t+1}^{i}$ :

$$
q_{t} \widetilde{k}_{t+1}^{i}=n_{t+1}^{i}+b_{t+1}^{i}
$$

The entrepreneur borrows from a financial intermediary that obtains its funds from households, with an opportunity cost equal to the riskless gross rate of return, $r_{t}$. In equilibrium, the intermediary holds a pooled, and perfectly safe, portfolio and the entrepreneurs absorb any aggregate risk.

BGG follow a "costly state verification" approach like in Townsend (1979), where lenders must pay a fixed auditing cost to observe an individual borrower's realized return. They assume monitoring costs to be a proportion $\mu$ of the realized gross payoff to the firms' capital, i.e., monitoring costs equal $\mu \omega_{t+1}^{i} r_{t+1}^{k} q_{t} \widetilde{k}_{t+1}^{i} \cdot{ }^{4}$ When $\mu=0$, we are in the special case of frictionless financial markets.

The optimal contract will be incentive compatible, characterized by a schedule of state contingent threshold values of the idiosyncratic shock $\varpi_{t+1}^{i}$, such that for values of the idiosyncratic shock greater than the threshold, the entrepreneur is able to repay the lender, and for values below the threshold, the entrepreneur declares default and the lender obtains $(1-\mu) \omega_{t+1}^{i} r_{t+1}^{k} q_{t} \widetilde{k}_{t+1}^{i}$. Only one-period contracts between borrowers and entrepreneurs are feasible.

Under these assumptions, the optimal contract is chosen to maximize expected entrepreneurial utility, conditional on the expected return of the lender, for each possible realization of $r_{t+1}^{k}$, being equal to the riskless rate, $r_{t}$. BGG show that two first-order conditions must hold in the optimal contract between entrepreneurs and banks, namely:

$$
E_{t}\left\{\left(1-\Gamma\left(\varpi_{t+1}^{i}\right)\right) \frac{r_{t+1}^{k}}{r_{t}}+\lambda\left(\varpi_{t+1}^{i}\right)\left[\left(\Gamma\left(\varpi_{t+1}^{i}\right)-\mu G\left(\varpi_{t+1}^{i}\right)\right) \frac{r_{t+1}^{k}}{r_{t}}-1\right]\right\}=0
$$

and

$$
\left[\Gamma\left(\varpi_{t+1}^{i}\right)-\mu G\left(\varpi_{t+1}^{i}\right)\right] r_{t+1}^{k} q_{t} \widetilde{k}_{t+1}^{i}=r_{t}\left[q_{t} \widetilde{k}_{t+1}^{i}-n_{t+1}^{i}\right]
$$

\footnotetext{
${ }^{4}$ The relevant price here is $q_{t}$ since capital price gains are included in $r_{t+1}^{k}$.
} 
where $\mu G\left(\varpi_{t+1}^{i}\right)=\mu \int_{0}^{\varpi_{t+1}^{i}} \omega d F(\omega)$ is expected monitoring costs, $\Gamma\left(\varpi_{t+1}^{i}\right)=\left(1-F\left(\varpi_{t+1}^{i}\right)\right) \varpi_{t+1}^{i}+$ $G\left(\varpi_{t+1}^{i}\right)$ is the expected gross share of profits going to the lender, and $\lambda\left(\varpi_{t+1}^{i}\right)=$ $\frac{\Gamma^{\prime}\left(\varpi_{t+1}^{i}\right)}{\Gamma^{\prime}\left(\varpi_{t+1}^{i}\right)-\mu G^{\prime}\left(\varpi_{t+1}^{i}\right)}$.

From the first first-order condition, we see that when financial markets are frictionless, $\mu=0, \lambda\left(\varpi_{t+1}^{i}\right)=1$ and $E_{t} r_{t+1}^{k}=r_{t}$ : the ex-ante return on capital equals the risk free rate when there are no monitoring costs. The second first-order condition is related to the fact that the financial intermediary receives an expected return equal to the opportunity cost of its funds. In this case, the lender's expected return can simply be expressed as a function of the average cutoff value of the firm's idiosyncratic shock, $\varpi_{t+1}$.

Since the entrepreneur is risk neutral, he only cares about the mean return on his wealth. He guarantees the lender a return that is free of any systematic risk: conditional on $r_{t+1}^{k}$, he offers a state-contingent contract that guarantees the lender a expected return equal to the riskless rate.

From these two equations, aggregation is straightforward and it can be shown that capital expenditures by each entrepreneur $i$ are proportional to his net worth. Aggregate entrepreneurial net worth (in consumption units) at the end of period $t, n_{t+1}$ is given by

$$
n_{t+1}=\gamma\left\{r_{t}^{k} q_{t-1} \widetilde{k}_{t}-\left[r_{t-1}\left(q_{t-1} \widetilde{k}_{t}-n_{t}\right)+\mu \int_{0}^{\varpi_{t}} \omega d F(\omega) r_{t}^{k} q_{t-1} \widetilde{k}_{t}\right]\right\}+w^{e},
$$

where $\gamma$ is the fraction of entrepreneurs surviving to the next period, and $w^{e}$ are government net transfers to entrepreneurs. In each period, a fraction $(1-\gamma)$ of new entrepreneurs enters the market receiving some transfers and the wealth of the fraction that did not survive is given to the government.

\subsubsection{Optimal Capital Utilization Decision}

After observing the shocks at the beginning of period $t+1$, entrepreneurs decide how intensively to use their capital. Higher capital utilization is costly because of higher depreciation rates. ${ }^{5}$ This is an important assumption because it allows for variable capital utilization, a relevant feature in the data. Entrepreneurs choose capital utilization, $u_{t+1}$

\footnotetext{
${ }^{5}$ This approach has been used by Baxter and Farr (2005), among others.
} 
to solve

$$
\max _{u_{t+1}}\left[\frac{u_{t+1} z_{t+1}+\left(1-\delta\left(u_{t+1}\right)\right) q_{t+1}}{q_{t+1}}\right] .
$$

\subsection{Monetary and Fiscal Policy}

The monetary authority conducts monetary policy by controlling the gross nominal interest rate, $r_{t}^{n}$. For convenience, I assume a cashless economy, but the monetary authority can set the interest rate directly in the inter-bank market. The loglinearized monetary policy rule is

$$
\widehat{r}_{t}^{n}=\rho^{r} \widehat{r}_{t-1}^{n}+\left(1-\rho^{r}\right)\left[\gamma^{\pi} E \widehat{\pi}_{t+1}+\gamma^{y} \widehat{y}_{t} / 4\right]+\widehat{\varepsilon}_{t}^{r},
$$

where letters with a hat represent $\log$ deviations from the steady state, $\widehat{\varepsilon}_{t}^{r}$ is an iid monetary policy shock with mean zero and $\widehat{\pi}_{t+1}$ is the inflation rate in $t+1$.

Government consumption expenditures, $g_{t}$, follow a first-order autoregressive process. The government finances its expenditures by lump-sum taxes, $t_{t}$, and nominal bonds, $\mathrm{nb}_{t+1}$. I assume the government elastically supplies bonds until the bond market clears and the resulting fiscal surplus/deficit is adjusted with lump-sum taxes to the households.

\subsection{Competitive Equilibrium}

In a competitive equilibrium, all the above optimality conditions are satisfied. In addition, markets clear. The aggregate resource constraint is

$$
y_{t}=c_{t}+i_{t}+g_{t}+\mu \int_{0}^{\bar{\omega}_{t}} \omega d F(\omega) r_{t}^{k} q_{t-1} \widetilde{k}_{t} .
$$

Final goods are allocated to consumption, investment, government expenditure and monitoring costs associated with defaulting entrepreneurs. Furthermore, credit markets clear and $b_{t}=d_{t}$.

\section{Methodology for Estimation and Model Evalua- tion}

To solve the model, I loglinearize the equilibrium conditions around their steady state values. In Appendix A, the loglinearized version of the model is presented. Then, the 
method described in Sims (2002) (and the companion matlab code gensys.m) is used to solve the linearized model.

The model has a total of 30 free parameters. Seven of these are calibrated to their steady state values, as they cannot be identified from the detrended data. The steady state rate of depreciation of capital $\delta$ is set equal to 0.025 , which corresponds to an annual rate of depreciation of ten percent. The discount factor $\beta$ is set at 0.99 , which corresponds to an annual real rate of four percent in steady state. The steady state share of government spending was set equal to 19.5 percent. ${ }^{6}$ The parameter of the Cobb-Douglas production function, $\alpha$, was set equal to 0.33 , while the steady state price mark up, $\lambda$, was set at 20 percent. These values imply steady state consumption and investment ratios of 60.9 and 19.6 percent in models without financial frictions. ${ }^{7}$ Moreover, the steady state wage mark up, $\tau$, was set equal to five percent, and the steady state probability of default, $F(\varpi)$, equal to three percent per year, the same value as BGG. ${ }^{8}$

The remaining 23 parameters are estimated using Bayesian procedures. I start by solving the model for an initial set of parameters. Then, the Kalman Filter is used to calculate the likelihood function of the data (for given parameters). Combining prior distributions with the likelihood of the data gives the posterior kernel which is proportional to the posterior density. Since the posterior distribution is unknown, I use Markov Chain Monte Carlo (MCMC) simulation methods to conduct inference about the parameters.

To check convergence, I run different chains starting from different and dispersed points. Each set of estimates is based on two different chains starting from the mode of the posterior plus-minus two standard deviations, with a total of 100,000 draws in each simulation and a burn-in period of $50,000 .{ }^{9}$ Convergence was monitored calculating the potential scale reduction as described in Gelman, Carlin, Stern, and Rubin (2004), which declines to 1 as convergence is achieved. This ratio was computed for all parameters.

\footnotetext{
${ }^{6}$ Since this number does not include transfers, we can assume the same value for the U.S. and the Euro area.

${ }^{7}$ In models with a financial accelerator, these ratios will also depend on the risk premium.

8 De Fiore and Uhlig (2005) report that average default rates are similar in the U.S. and the Euro area, i.e. between 3 and 4.5 percent.

${ }^{9}$ I use an adaptive algorithm where after the first round of simulations, I set the covariance matrix in the jumping distribution equal to that estimated in the first round.
} 


\subsection{Data}

The data used for the estimation corresponds to seven variables of the model: real output, real consumption, real investment, hours worked, nominal interest rate, inflation and real wages. I do not include any financial variables in the estimation. To compare the model with and without financial frictions, the former will have a natural advantage if financial variables are included since the BGG model performs poorly in terms of financial variables when $\mu=0$.

For the U.S., the data covers the period 1980Q1-2004Q1, while for the Euro area, it covers the period 1980Q1-2002Q4 (see Appendix B for details). In both cases, I use quarterly detrended data.

\subsection{Prior Distribution}

All prior distributions were selected from the normal, beta, gamma and uniform distributions, depending on the supports and characteristics of the parameters. The prior distributions are the same for the U.S. and the Euro area and are shown in Table 1.

Many of the priors are standard and follow the literature (Smets and Wouters (2007), Adolfson, Laséen, Lindé, and Villani (2007)). The relative risk aversion coefficient, $\sigma$, has a normal distribution with mode one; the habit persistence parameter, $h$, has a beta distribution with mode 0.70. The parameters determining prices and wages follow a beta distribution. The modes of the Calvo parameters $\theta$ and $\vartheta$, the probability of not adjusting prices and wages, were set equal to 0.70 , so that, on average, prices and wages adjust every ten months.

Some of the parameters are particular to the way I capture some frictions in the model. This is true for the elasticity of the capital price to the investment-capital ratio, $\varphi$. BGG set this parameter equal to -0.25 while King and Wolman (1996) use a value of -2 based on estimations of Chirinko (1993). Since there is not enough information about this parameter, I use a uniform prior distribution between -1 and 0 . The prior for $\delta^{\prime \prime} / \delta^{\prime}$ is a gamma distribution with a mode equal to one, following the calibration of Baxter and Farr (2005).

Other non-standard parameters in the model are those related to the financial fric- 
tions. Following BGG, the prior for monitoring costs, $\mu$, was assumed to be beta distributed with mode equal to 0.12 . The fraction of entrepreneurs surviving to the next period, $\gamma$, has a beta distribution with a mode of 0.975 which implies that, on average, entrepreneurs live for ten years. Finally, the prior for the steady state external risk premium (the difference between the cost of funds raised externally and the opportunity cost of funds), $r^{k}-r$, was set gamma distributed with a mode 0.005 , which corresponds to an annual $2 \%$ risk premium as in BGG.

The priors for the long-run weights on inflation and output in the central bank reaction function are based on a standard Taylor rule, where $\gamma^{\pi}$ and $\gamma^{y}$ are normally distributed with mode 1.5 and 0.5 , respectively. The interest rate smoothing parameter, $\rho_{r}$, follows a beta distribution with mode 0.85 .

Regarding the shocks affecting the economy, the autoregressive coefficients have a beta distribution with mode 0.85 , while the standard deviations for the shocks follow a gamma distribution with mode 0.01 for the monetary, technology and government shocks, and 0.10 for the other shocks.

\subsection{Model Comparison}

To pairwise compare the performance of the different models, I calculate the posterior odds ratio. Since I set the prior odds equal to one, the posterior odds ratio is the ratio of the marginal data densities between models $i$ and $j$. I use the modified harmonic mean to approximate the marginal likelihood.

\section{Results}

\subsection{U.S.}

\subsubsection{Frictions in the U.S.}

In Table 2, I report the log marginal data density and posterior odds ratio for the two versions of the model: with and without credit frictions. The posterior odds ratio of the model with financial frictions against the model without financial frictions is $10^{21}$ to 
one, which is decisive evidence against the model without a financial accelerator. ${ }^{10}$ This extends the findings by Christensen and Dib (2007) who estimate the standard BGG model with maximum likelihood and provide evidence in favor of a financial accelerator.

In addition to the prior distributions, Table 1 also reports the mean and the 5 th and 95th percentile of the posterior distribution for U.S. data. ${ }^{11}$ The table shows that the estimated mean of monitoring costs is twelve percent. It is very interesting to see that this result is in line with the results of Levin, Natalucci, and Zakrajsek (2004). Using microdata for 900 U.S. firms over the period 1997Q1 to 2003Q3, they estimate that timevarying monitoring cost moved between eight and sixteen percent between 1997 and 1999 . When they smooth through a spike in 1998Q4, the average monitoring costs during this period is close to twelve percent of the realized gross payoff to the firms' capital. After the fall of the stock market in 2000, monitoring costs went up to reach values as high as forty percent, and then once more declined in 2003.

\subsubsection{Parameter Estimates for the U.S.}

Table 1 shows that the estimated posterior mean of the risk premium in steady state, $r k-r$, implies an annual premium of 2.4 percent, which is in line with the value used by BGG and Christiano, Motto, and Rostagno (2003), and falls in the 1.9-3.0 interval reported in De Fiore and Uhlig (2005). Together with other parameters, this value implies that the investment-output ratio and consumption-output ratio in steady state are 17 and 63 percent, respectively. Moreover, the fraction of GDP used in bankruptcy costs is around 0.4 percent on average, and the mean for the fraction of entrepreneurs

\footnotetext{
${ }^{10}$ In results available on request, I start out by estimating the standard BGG model, with and without financial frictions, and then add sequentially four frictions not present in that model: price indexation to past inflation, sticky wages, external habit formation in consumption and variable capital utilization. In all the cases, the posterior odds test favors the financial accelerator model. Moreover, the size of monitoring costs decreases once we introduce other frictions to the standard BGG model. In the standard BGG case, monitoring costs are almost twice as large as the ones presented below. The intuition is that higher monitoring costs are necessary in the standard BGG model to capture the dynamics of the data. Once other frictions are introduced, however, the data does not require such large financial frictions.

11 In results available on request, I show that all the posterior estimates converge to a stationary distribution. The only parameter which presents some doubts is the variance of the wage mark up shocks, $\sigma^{\tau}$. However, relatively small changes in the value of this parameter do not affect the properties of the model since it is multiplied by a very small number in the solution. Moreover, the data is informative to identify all the parameters, except for $\delta^{\prime \prime} / \delta^{\prime}$. In this one case, the use of a prior is similar to calibration. Nevertheless, small changes in this parameter do not affect the properties of the model when the impulse response functions are plotted.
} 
who survive, $\gamma$, is 0.99 , implying an average duration of entrepreneurial activities of 27 years. $^{12}$

Table 1 indicates that the four autoregressive shocks affecting the economy are very persistent as compared to the priors.

The coefficients describing consumer preferences do not differ substantially from the priors. The mean of risk aversion is 1.1 rather than one as the prior, and the habit persistence parameter has a posterior mean of 0.60 as compared to the prior mean of 0.70 .

The posterior mean of $\theta$ implies that prices on average adjust once every fourteen months, similarly to the result in Smets and Wouters (2007). In the case of wages, the average duration of contracts is estimated at only four months and is lower than the estimated value in other studies. Both the elasticity of capital price with respect to the investment capital ratio, $\varphi$, and the variable depreciation parameter, $\delta^{\prime \prime} / \delta^{\prime}$, have a similar posterior mean as the prior: -0.47 and 1.02 , respectively.

Concerning the coefficients in the central bank Taylor rule, all coefficients differ from their priors. The posterior mean for the coefficient on future inflation, $\gamma^{\pi}$, is 1.61 , while the coefficients on output, $\gamma^{y}$, and past interest rate, $\rho_{r}$, have a posterior mean of 0.24 and 0.43 respectively. Moreover, the response to inflation and output is lower than that estimated in Clarida, Gali, and Gertler (2000) using GMM methods.

When the model is estimated without monitoring costs (no financial accelerator), the results are robust for most of the parameters, except for two: the elasticity of the price of capital with respect to the investment-capital ratio, $\varphi$, and the entrepreneurs' rate of survival, $\gamma$. Both these parameters are higher in the model with financial frictions. A possible explanation is that investment reacts more to shocks in a model with a financial accelerator, which requires higher adjustment costs to match the dynamics of investment in the data. This implies that monitoring costs are not relevant because the model cannot explain investment behavior without them, but because monitoring costs help explain other variables. Moreover, to ensure that self-financing never occurs, estimates

\footnotetext{
12 These values imply an elasticity of the external finance premium with respect to the leverage ratio of 0.04, which is the same value estimated by Christensen and Dib (2007). The implied standard deviation of the idiosyncratic shock, $\sigma_{\omega}$, is 0.13 .
} 
of the probability of survival are lower in a frictionless credit market model. In addition, monetary policy reacts slightly more to output in the case with financial frictions which dampens the amplification of output fluctuations caused by the financial accelerator.

\subsection{Euro Area}

\subsubsection{Frictions in the Euro Area}

Table 2 shows that the posterior odds ratio for the hypothesis of financial frictions versus no financial frictions in the Euro area is $10^{17}$ to one, which clearly favors a model with monitoring costs. Table 3 shows that the posterior mean of monitoring costs in the Euro area is 18 percent, fifty percent higher than the cost estimated for the U.S., and outside the 90 percent confidence bands for the U.S. As for the U.S., the data thus prefers a model with credit market imperfections, but these imperfections seem to be larger in the Euro area. ${ }^{13}$

\subsubsection{Parameter Estimates for the Euro Area}

Table 3 reports the mean and the 5th and 95th percentile of the posterior distribution of the model with and without financial frictions in the Euro area. ${ }^{14}$ The posterior distribution of the parameters using European data is in general very similar to that of the U.S. This indicates that the shocks driving the economy and the transmission mechanisms in the two areas are not too different. However, some parameters display more distinct differences.

The fact that monitoring costs are larger in the Euro area drives up the external risk premium: in the Euro area, the posterior mean of the annual risk premium is 3.6 percent in steady state. This value is slightly higher that the one reported in De Fiore and Uhlig (2005) for Euro data: they report a risk premium on loans between 1.6 and

\footnotetext{
${ }^{13}$ As for the U.S., I start estimating the standard BGG model and then add, one at a time, price indexation to past inflation, sticky wages, consumption habits and variable capital utilization. In all the cases, the data clearly favors a model with monitoring costs, which reach values as high as 52 percent in the model with price indexation and sticky wages. Moreover, for each model, the estimated mean of monitoring costs is higher than in the U.S.

14 The value of the potential scale reduction indicates some convergence problems for the parameters governing variable capital depreciation and preference shocks. However, small changes in the value of these parameters do not affect the properties of the model when the impulse response functions are plotted.
} 
2.7 percent. The estimated risk premium implies that in steady state, the investment and consumption ratio to output are 15.6 and 64.3 percent, respectively, and that the fraction of GDP used in bankruptcy cost is 0.6 percent.

Concerning the size of the shocks, monetary shocks are smaller in the Euro area, which is consistent with the results in Angeloni, Kashyap, Mojon, and Terlizzese (2003) and Smets and Wouters (2005). Another difference is that preference shocks are larger in the Euro area, while wage mark up shocks are smaller. When it comes to persistence, technology shocks are slightly more persistent in the Euro area, while government spending shocks are less persistent.

The mean of risk aversion in the Euro area is 1.2 and the parameter of consumption habit formation is around 0.50 .

Concerning price stickiness, prices on average adjust every six quarters. This implies that prices are more sticky in the Euro area, consistent with Peersman and Smets (2001) who find that the impact on prices after a monetary shock is faster in the U.S. Moreover, wage behavior is very similar to the U.S.: wages change every four months on average.

The elasticity of the price of capital with respect to the investment capital ratio, $\varphi$, is larger in Europe, with a mean value of -0.97. Given larger monitoring costs in the Euro area, the model requires higher adjustment costs in investment to dampen the response of investment after a shock. In the model, these two effects offset each other and investment responds similarly in the U.S. and the Euro area after most of the shocks.

The coefficients in the monetary rule are similar in both areas, and different from the prior, thereby suggesting that both areas have responded in a similar way to expected inflation and output in the last twenty years. As in the case of the U.S., the response of the interest rate to output is stronger in the model with financial frictions.

\subsection{Robustness}

Since the assessment of the importance of financial frictions relies on a clear identification of monitoring costs, I check the robustness of my results changing the prior for $\mu$. As discussed in Canova and Sala (2006), the posterior of parameters presenting identification problems becomes more diffuse once we use more diffuse priors. Hence, they suggest using 
a sequence of prior distributions with larger variances to detect potential identification problems. Figure 1 plots the prior and posterior distribution of $\mu$ in both areas. The first row corresponds to a beta prior for $\mu$ with mode 0.12 and standard deviation 0.05 . The second row corresponds to a beta prior with mode 0.12 and standard deviation 0.10 . The figure shows than once we increase the prior variance of $\mu$, the posterior does not become more diffuse. This strengthen the result that monitoring costs are well identified and, as shown in the figure, monitoring costs are larger in the Euro area, independently of the prior I choose.

\section{Discussion}

The results show that frictions in financial markets are important both in the U.S. and the Euro area. Moreover, these frictions are larger in the Euro area. This is in line with independent observations suggesting that financial markets are more developed and integrated in the U.S., and that the institutional and legal framework in the two areas differ. Evidently, such discrepancies translate into a less efficient credit market. Moreover, the U.S. has a more fragmented banking sector than the Euro area and a larger number of publicly listed firms 'per capita', which may also imply a more transparent and competitive market.

A number of studies have documented these kinds of differences in financial markets on the two sides of the Atlantic. For instance, Cecchetti (1999) shows the Thomson rating to be lower in the U.S., meaning a more efficient banking system. Moreover, while the return on assets is higher in the U.S., loan losses are lower. In the model, loan losses are an increasing function of monitoring costs and though, consistent with higher monitoring costs in the Euro area.

De Fiore and Uhlig (2005) find that investment of the corporate sector relies much more heavily on bank finance in the Euro area than in the U.S.: bank to bond finance ratios are 7.3 and 0.74 , respectively. If we also consider that the cost of acquiring information is higher for banks, these two facts imply higher monitoring cost in the Euro area, consistent with the results in my paper. However, in contrast to my paper, De Fiore and 
Uhlig report that risk premiums on loans are higher in the U.S.

The financial market structure can play an important role in the transmission mechanism of shocks and the decisions of firms. The fact that the Euro area presents more frictions in credit markets than the U.S. might generate different investment dynamics. For example, a model with larger monitoring costs has a more powerful financial accelerator and hence greater response of investment to a monetary policy shock ceteris paribus.

Figure 2 shows the impulse response functions to a monetary policy shock of equal size in both economies, evaluated at the posterior mean. Even though monitoring costs are larger in the Euro area, the response of investment is similar in both economies. In the model, this is due to higher investment adjustment costs in the Euro area, which offset the larger credit frictions. ${ }^{15}$

To check that this result is not caused by other parameters in the model, I perform a counterfactual analysis. In Figure 3, I plot the impulse response function to a monetary policy shock of the estimated model for the U.S. (evaluated at the mean of the posterior). I then repeat the same exercise only changing the value of three parameters: monitoring costs, steady state risk premium and investment adjustment costs. I set these three parameters equal to their mean estimates for the Euro area. The figure shows that larger monitoring costs in the Euro area are offset by larger adjustment costs, such that on impact, investment reacts less, which also causes a smaller fall in output. However, the existence of higher monitoring costs implies a higher response of the costs of funds in the Euro area.

Figure 4 shows the same counterfactual exercise in the case of a productivity shock. The figure shows that higher financial frictions are once more offset by higher capital adjustment costs and investment reacts less, even though the financial accelerator effect is stronger. A positive productivity shock increases the marginal productivity of capital and thus the rental price of capital, the return on capital, the demand for capital and the price of capital. This has a positive effect on net worth and with higher financial frictions, these effects are larger through the positive effect on net worth. For instance,

\footnotetext{
${ }^{15}$ De Walque, Smets, and Wouters (2005) also find that adjustment costs in capital accumulation are larger in the Euro area.
} 
the higher price of capital under higher financial frictions increases the rental price of capital. Moreover, a positive productivity shock decreases the marginal costs given the increase in the marginal productivity of labor and capital. The initial fall in marginal costs is lower when financial frictions are larger since the increase in the rental price of capital is also larger. This difference in marginal costs causes a lower decrease in inflation on impact and in the next periods. This shows that the behavior of inflation and nominal interest rates after a productivity shock can favor a model with higher financial frictions and adjustment costs, even though the path of investment and output is not very different in the two scenarios.

Last, Figure 5 shows the impulse response function to a preference shock in the same counterfactual scenario. Now, the model with higher monitoring costs and capital adjustment costs has a much lower response of investment, but a similar path for inflation and the nominal interest rate.

The counterfactual exercises documented in Figures 3-5 show that financial frictions and capital adjustment costs are not observationally equivalent. Financial frictions do not only affect the response of investment and output after a shock, but also the path of other observable variables. It is only by considering the response of macro variables to a large number of shocks, that we can disentangle the effects of financial frictions and capital adjustment costs. This result explains the differences found in previous papers estimating the financial accelerator model. For instance, Meier and Muller (2006) find that after a monetary policy shock, a model with financial frictions does not necessarily better fit the data. However, they do not consider the response of the economy to other shocks. On the other hand, this paper extends the findings by Christensen and Dib (2007) providing evidence in favor of a financial accelerator.

\section{Conclusions}

I study an extended version of the BGG model augmented with other frictions, such as price indexation to past inflation, sticky wages, consumption habits and variable capital utilization. This model allows us to quantify credit market frictions in an economically 
meaningful way. The model is estimated using Bayesian techniques for both the U.S. and the Euro area.

The results indicate that financial frictions are relevant in both areas, but quantitatively more important in the Euro area. This suggests that the financial market structure can play an important role in the transmission mechanism of shocks and the decisions of firms. The fact that the Euro area has larger credit market frictions might lead one to believe that it has different investment dynamics than in the U.S. In actual fact, however, the response of investment is similar in both economies after most shocks. In the model, this is due to higher investment adjustment costs in the Euro area, which offset the larger credit frictions. Higher financial frictions in the Euro area do generate different responses of prices, the nominal interest rate and the external risk premium, though. I show that only considering the response of the variables to a large number of shocks makes it possible to disentangle these two effects.

As mentioned before, the paper only analyzes whether financial frictions are important as a source of propagation of shocks. A natural extension of the model should allow for financial frictions as a source of shocks: shocks originating from the financial side of the economy. This can be an important component when comparing business cycle dynamics in the U.S. and in the Euro area.

\section{References}

Adolfson, M., S. Laséen, J. Lindé, and M. Villani (2007): "Bayesian Estimation of an Open Economy DSGE Model with Incomplete Pass-Through," Journal of International Economics, 72, 481-511.

Angeloni, I., A. Kashyap, B. Mojon, and D. Terlizzese (2003): "The Output Composition Puzzle: A Difference in the Monetary Transmission Mechanism in the Euro Area and U.S.," Journal of Money, Credit and Banking, 35(6, Part 2), 12651306.

Baxter, M., And D. FARr (2005): "Variable Capital Utilization and International Business Cycles," Journal of International Economics, 65(2), 335-347. 
Bernanke, B., And M. Gertler (1989): "Agency Costs, Net Worth and Business Fluctuations," American Economic Review, 79(1), 14-31.

Bernanke, B., M. Gertler, and S. Gilchrist (1996): "The Financial Accelerator and the Flight to Quality," Review of Economic Studies, 78(1), 1-15.

(1999): "The Financial Accelerator in a Quantitative Business Cycle Framework," in Handbook of Macroeconomics, ed. by J. B. Taylor, and M. Woodford, vol. 1C, chap. 21, pp. 1341-93. North-Holland, Amsterdam.

Canova, F., And L. SAla (2006): "Back to Square One: Identification Issues in DSGE Models," ECB Working Paper Series No 583.

Carlstrom, C. T., and T. S. Fuerst (1997): "Agency Costs, Net Worth, and Business Fluctuations: A Computable General Equilibrium Analysis," American Economic Review, 87(5), 893-910.

Cecchetti, S. G. (1999): "Legal Structure, Financial Structure, and the Monetary Policy Transmission Mechanism," FRBNY Economic Policy Review, 5(2).

Chirinko, R. (1993): "Business fixed investment spending: A Critical Survey of Modelling Strategies, Empirical Results and Policy Implications," Journal of Economic Literature, 31, 1875-1911.

Christensen, I., And A. Dib (2007): "The Financial Accelerator in an Estimated New Keynesian Model," Review of Economic Dynamics (forthcoming).

Christiano, L. J., M. Eichenbaum, and C. L. Evans (2005): "Nominal Rigidities and the Dynamic Effects of a Shock to Monetary Policy," Journal of Political Economy, 113(1), 1-45.

Christiano, L. J., R. Motto, and M. Rostagno (2003): "The Great Depression and the Friedman-Schwartz Hypothesis," Journal of Money, Credit and Banking, 35(6), $1119-1197$. 
Clarida, R., J. Gali, and M. Gertler (2000): "Monetary Policy Rules and Macroeconomic Stability: Evidence and Some Theory," Quarterly Journal of Economics, 115(1), 147-80.

De Fiore, F., and H. Uhlig (2005): "Bank Finance versus Bond Finance: What Explains the Differences between the US and Europe?," Centre for Economic Policy Research, Discussion Paper No. 5213.

De Walque, G., F. Smets, and R. Wouters (2005): "An Estimated Two-Country DSGE Model for the Euro Area and the US Economy," Manuscript, EEA-ESEM Conference 2006 .

Gelman, A., J. B. Carlin, H. S. Stern, and D. B. Rubin (2004): Bayesian Data Analysis. Chapman and Hall/CRC, second edn.

Groth, C., And H. Khan (2007): "Investiment Adjustment Costs: An Empirical Assessment," Manuscript, Carleton University.

King, R. G., and A. L. Wolman (1996): "Inflation Targeting in a St. Louis model of the 21st Century," Federal Reserve Bank of St. Louis, Review.

Levin, A. T., F. M. Natalucci, and E. Zakrajsek (2004): "The Magnitude and Cyclical Behavior of Financial Market Frictions," Finance and Economics Discussion Series, Federal Reserve Board, Washington DC.

Meier, A., And G. Muller (2006): "Fleshing our the Monetary Transmission Mechanism: Output Composition and the Role of Financial Frictions," Journal of Money, Credit and Banking, 38(8), 2099-2133.

Peersman, G., and F. Smets (2001): "The Monetary Transmission Mechanism in the Euro Area: More Evidence from VAR Analysis," ECB, Working Paper 91.

Sims, C. A. (2002): "Solving Linear Rational Expectations Models," Computational Economics, 20(1-2), 1-20. 
Smets, F., And R. Wouters (2003): "An Estimated Dynamic Stochastic General Equilibrium Model of the Euro Area," Journal of the European Economic Association, $1(5), 1123-1175$.

(2005): "Comparing Shocks and Frictions in US and Euro Area Business Cycles:

A Bayesian Approach," Journal of Applied Econometrics, 20, 161-183.

(2007): "Shocks and Frictions in US Business Cycles: A Bayesian DSGE Approach," American Economic Review, 97(3), 586-606.

\section{A The log-linearized model}

To solve the model, I loglinearize the equilibrium conditions around their steady state values. Letters with a hat represent log deviations from the steady state at time $t$, and letters without a subscript represent the steady state values of the variables.

The loglinearized versions of aggregate demand and supply are

$$
\widehat{y}_{t}=\frac{c}{y} \widehat{c}_{t}+\delta \frac{\widetilde{k}}{y} \widehat{i}_{t}+\frac{g}{y} \widehat{g}_{t}+\frac{\mu G(\varpi) r^{k} \widetilde{k}}{y}\left(\widehat{r}_{t}^{k}+\widehat{q}_{t-1}+\widehat{\widetilde{k}}_{t}\right)+\frac{\mu r^{k} G^{\prime}(\varpi) \widetilde{k} \varpi}{y} \widehat{\varpi}_{t}
$$

and

$$
\widehat{y}_{t}=\widehat{a}_{t}+\alpha \widehat{k}_{t}+(1-\alpha) \widehat{L}_{t}
$$

where $\delta$ is the steady state capital depreciation.

The consumption Euler equation, the arbitrage condition for nominal bonds and the law of motion of real wages are

$$
\begin{gathered}
\widehat{c}_{t}=\frac{(1-h)}{\sigma(1+h)}\left(\widehat{\nu}_{t}-E_{t} \widehat{\nu}_{t+1}\right)+\frac{h}{(1+h)} \widehat{c}_{t-1}-\frac{(1-h)}{\sigma(1+h)} \widehat{r}_{t}+\frac{E_{t} \widehat{c}_{t+1}}{(1+h)} \\
\widehat{r}_{t}^{n}=\widehat{r}_{t}+E_{t} \widehat{\pi}_{t+1} \\
E_{t}\left\{\eta_{0} \widehat{w}_{t-1}^{r}+\eta_{1} \widehat{w}_{t}^{r}+\eta_{2} \widehat{w}_{t+1}^{r}+\eta_{3} \hat{\pi}_{t-1}+\eta_{4} \hat{\pi}_{t}+\eta_{5} \hat{\pi}_{t+1}+\eta_{6} \widehat{L}_{t}+\eta_{7}\left(\widehat{c}_{t}-h \widehat{c}_{t-1}\right)+\eta_{8} \widehat{\xi}_{t}+\eta_{9} \widehat{\tau}_{t}\right\}=0
\end{gathered}
$$


where $b_{w}=[(\tau+1)+\tau] /[(1-\vartheta)(1-\beta \vartheta)]$ and

$$
\eta=\left(\begin{array}{c}
b_{w} \vartheta \\
-b_{w}\left(1+\beta \vartheta^{2}\right)+(\tau+1) \\
\beta \vartheta b_{w} \\
b_{w} \vartheta \\
-\vartheta b_{w}(1+\beta) \\
b_{w} \beta \vartheta \\
\tau \\
\tau \sigma(1-h)^{-1} \\
\tau \\
\tau \frac{\tau}{\tau+1}
\end{array}\right)=\left(\begin{array}{c}
\eta_{0} \\
\eta_{1} \\
\eta_{2} \\
\eta_{3} \\
\eta_{4} \\
\eta_{5} \\
\eta_{6} \\
\eta_{7} \\
\eta_{8} \\
\eta_{9}
\end{array}\right) .
$$

These three equations are derived from the households' first-order conditions. $\tau$ is the net wage mark up in steady state; $\widehat{\nu}_{t}$ is the preference shock, and $\widehat{\xi}_{t}$ is the labor supply shock.

The demands for labor and capital in the wholesale sector, where factor prices are equal to marginal productivity plus real marginal cost, $\widehat{s}_{t}$, are given by

$$
\widehat{y}_{t}-\widehat{L}_{t}+\widehat{s}_{t}=\widehat{w}_{t}^{r}
$$

and

$$
\widehat{s}_{t}+\widehat{y}_{t}-\widehat{k}_{t}=\widehat{z}_{t}
$$

A Phillips curve can be derived from the wholesale sector optimization problem for prices, where $(1-\theta)$ is the probability of adjusting prices and $\lambda$ is the net price mark up in steady state:

$$
\widehat{\pi}_{t}=\frac{\widehat{\pi}_{t-1}}{(1+\beta)}+\frac{\beta}{(1+\beta)} E_{t} \widehat{\pi}_{t+1}+\frac{(1-\theta)(1-\beta \theta)}{(1+\beta) \theta} \widehat{s}_{t}+\frac{(1-\theta)(1-\beta \theta)}{(1+\beta) \theta} \frac{\lambda}{(\lambda+1)} \widehat{\lambda}_{t} .
$$

Capital producers' optimality condition is

$$
E_{t} \widehat{q}_{t+1}+\varphi\left[\widehat{i}_{t+1}-\widehat{\widetilde{k}}_{t+1}\right]=0
$$

This equation links asset prices and investment, where $\varphi=\Phi^{\prime \prime}\left(\frac{i}{k}\right)\left(\frac{i}{k}\right)$ is the elasticity of the price of capital with respect to the investment-capital ratio.

The equilibrium conditions of the entrepreneurs are

$$
E_{t} \widehat{r}_{t+1}^{k}-\widehat{r}_{t}=E_{t} \widehat{\varpi}_{t+1} \varpi \frac{r^{k}}{r}(1-\Gamma(\varpi))\left[\frac{\Gamma^{\prime \prime}(\varpi)}{\lambda(\varpi) \Gamma^{\prime}(\varpi)}-\frac{\Gamma^{\prime \prime}(\varpi)}{\Gamma^{\prime}(\varpi)}+\frac{\mu G^{\prime \prime}(\varpi)}{\Gamma^{\prime}(\varpi)}\right],
$$




$$
\begin{gathered}
{\left[(1-F(\varpi))-\mu G^{\prime}(\varpi)\right] \frac{\widetilde{k}}{n} \frac{r^{k}}{r} \varpi \widehat{\varpi}_{t+1}+\left[\frac{\widetilde{k}-n}{n}\right]\left(\widehat{r}_{t+1}^{k}-\widehat{r}_{t}\right)=\widehat{\widetilde{k}}_{t+1}+\widehat{q}_{t}-\widehat{n}_{t+1},} \\
\widehat{k}_{t}=\widehat{u}_{t}+\widehat{\widetilde{k}}_{t},
\end{gathered}
$$

and

$$
\widehat{z}_{t+1}=\frac{\delta^{\prime \prime}(1)}{\delta^{\prime}(1)} \widehat{u}_{t+1}+\widehat{q}_{t+1} .
$$

Equations (10) and (11) are the first-order conditions of the optimal lending contract. Equation (12) relates capital services to the capital stock, while equation (13) is the optimality condition for capital utilization.

The loglinearized return on capital is

$$
\widehat{r}_{t+1}^{k}=\frac{z}{r^{k}} \widehat{z}_{t+1}+\frac{(1-\delta)}{r^{k}} \widehat{q}_{t+1}-\widehat{q}_{t}
$$

Equations (15) and (16) are the law of motion of net worth and capital, respectively:

$$
\widehat{n}_{t+1}=\gamma\left\{\begin{array}{c}
\left(\frac{\widetilde{k}-\mu G(\varpi) \widetilde{k}}{n}\right) r^{k} \widehat{r}_{t}^{k}+\left(\frac{r^{k} \widetilde{k}-\widetilde{k} r-\mu G(\varpi) r^{k} \widetilde{k}}{n}\right) \widehat{q}_{t-1}+\left(\frac{r^{k}-r-\mu G(\varpi) r^{k}}{n}\right) \widetilde{k}_{\vec{k}} \\
-\left(\frac{\widetilde{k}-n}{n}\right) r \widehat{r}_{t-1}+r \widehat{n}_{t}-\left(\frac{\mu r^{k} G_{w} \widetilde{k}}{n}\right) \varpi \widehat{\varpi}_{t}
\end{array}\right\}
$$

and

$$
\widehat{\widetilde{k}}_{t+1}=\widehat{\delta i}_{t}+(1-\delta) \widehat{\widetilde{k}}_{t}-\delta^{\prime}(1) \widehat{u}_{t}
$$

The loglinearized monetary policy rule is

$$
\widehat{r}_{t}^{n}=\rho^{r} \widehat{r}_{t-1}^{n}+\left(1-\rho^{r}\right)\left(\gamma^{\pi} E \widehat{\pi}_{t+1}\right)+\left(1-\rho^{r}\right)\left(\gamma^{y} \widehat{y}_{t}\right) / 4+\widehat{\varepsilon}_{t}^{r}
$$

There exist seven shocks in the model. The monetary policy, price mark up and wage mark up shocks are white noise shocks. The rest of the shocks in the model, labor supply, preferences, government spending and technology, follow a first-order autoregressive process.

\section{B Data}

U.S. data was taken from the Bureau of Economic Analysis of the U.S. Department of Commerce (BEA), the IMF database and the Bureau of Labor Statistics (BLS). Real output is measured by real GDP converted into per capita terms divided by the population 
aged above sixteen (P16). Real consumption is real personal consumption expenditures divided by P16. Real investment is real gross private domestic investment also in per capita terms. Hours worked are measured by the product of average weekly hours in the private sector times the population aged above twenty. The nominal interest rate is the Federal Funds Rate, and inflation is calculated as the difference of the GDP deflator. Real wages are measured by the average hourly earnings of production workers in real terms. All series were detrended with a linear trend and in the case of the interest rate, I used the same trend as inflation.

European data was taken from the AWM database of the ECB. One problem with a "synthetic" data set for the Euro area is how to aggregate and the fact that there is not a unique monetary policy at the beginning of the sample. However, this is the best available dataset. Real output is measured by real GDP converted into per capita terms divided by the labor force. Real consumption is real consumption divided by the labor force. Real investment is real gross investment also in per capita terms. To calculate hours worked, I use data on total employment, and transform it into hours worked using the same criterion as Smets and Wouters (2003). They assume that in any period, only a constant fraction of firms, $\xi_{e}$, is able to adjust employment to its desired total labor input. This results in the following equation for employment:

$$
\widehat{e}_{t}=\beta \widehat{e}_{t+1}+\frac{\left(1-\xi_{e}\right)\left(1-\beta \xi_{e}\right)}{\xi_{e}}\left(\widehat{l}_{t}-\widehat{e}_{t}\right) \text {, }
$$

where $\widehat{e}_{t}$ is total employment. In contrast to them, I do not estimate $\xi_{e}$, but following their results and the results in Adolfson, Laséen, Lindé, and Villani (2007), I fix it equal to 0.70 . The nominal interest rate is the quarterly short-term interest rate, and inflation is calculated as the difference of the GDP deflator. Real wages are measured by the wage rate deflated by the GDP deflator. All series were detrended with a linear trend and in the case of the interest rate, I used the same trend as inflation. 


\section{Tables and Figures}

Table 1: Prior and Posterior Distribution for the U.S.

\begin{tabular}{l|ccc|ccc|ccc}
\hline \hline Parameter & \multicolumn{4}{|c|}{ Prior } & \multicolumn{3}{|c|}{ Financial Accelerator } & \multicolumn{3}{c}{ no Fin. Accelerator } \\
& Type & Mode & St. Er. & $5 \%$ & Mean & $95 \%$ & $5 \%$ & Mean & $95 \%$ \\
\hline \hline$\sigma_{r}$ & Gam & 0.01 & 0.005 & 0.003 & 0.004 & 0.004 & 0.003 & 0.004 & 0.005 \\
$\sigma_{a}$ & Gam & 0.01 & 0.005 & 0.006 & 0.007 & 0.008 & 0.005 & 0.006 & 0.007 \\
$\sigma_{g}$ & Gam & 0.01 & 0.005 & 0.015 & 0.017 & 0.019 & 0.017 & 0.019 & 0.021 \\
$\sigma_{\nu}$ & Gam & 0.10 & 0.05 & 0.089 & 0.126 & 0.165 & 0.085 & 0.145 & 0.228 \\
$\sigma_{\xi}$ & Gam & 0.10 & 0.05 & 0.026 & 0.031 & 0.037 & 0.034 & 0.040 & 0.048 \\
$\sigma_{\lambda}$ & Gam & 0.10 & 0.05 & 0.271 & 0.329 & 0.397 & 0.215 & 0.260 & 0.312 \\
$\sigma_{\tau}$ & Gam & 0.10 & 0.05 & 1.877 & 2.143 & 2.414 & 2.164 & 2.438 & 2.740 \\
$\rho^{r}$ & Beta & 0.85 & 0.10 & 0.354 & 0.430 & 0.500 & 0.313 & 0.395 & 0.470 \\
$\rho^{a}$ & Beta & 0.85 & 0.10 & 0.953 & 0.976 & 0.993 & 0.896 & 0.923 & 0.945 \\
$\rho^{g}$ & Beta & 0.85 & 0.10 & 0.868 & 0.920 & 0.963 & 0.945 & 0.966 & 0.983 \\
$\rho^{\nu}$ & Beta & 0.85 & 0.10 & 0.991 & 0.993 & 0.996 & 0.990 & 0.994 & 0.997 \\
$\rho^{\xi}$ & Beta & 0.85 & 0.10 & 0.985 & 0.992 & 0.998 & 0.981 & 0.989 & 0.996 \\
$\gamma^{\pi}$ & Norm & 1.50 & 0.05 & 1.542 & 1.614 & 1.687 & 1.564 & 1.637 & 1.708 \\
$\gamma^{y}$ & Norm & 0.50 & 0.05 & 0.157 & 0.240 & 0.322 & 0.109 & 0.198 & 0.285 \\
$\sigma$ & Norm & 1.00 & 0.10 & 0.984 & 1.110 & 1.227 & 0.944 & 1.100 & 1.259 \\
$\theta$ & Beta & 0.70 & 0.05 & 0.758 & 0.782 & 0.804 & 0.734 & 0.759 & 0.783 \\
$\varphi$ & Unif & $-0.5 *$ & 0.29 & -0.578 & -0.475 & -0.386 & -0.278 & -0.220 & -0.168 \\
$\gamma$ & Beta & .975 & 0.01 & 0.985 & 0.991 & 0.995 & 0.952 & 0.971 & 0.985 \\
$\mu$ & Beta & 0.12 & 0.05 & 0.083 & 0.119 & 0.158 & - & - & - \\
$\gamma^{k}-r$ & Gam & 0.005 & 0.002 & 0.004 & 0.006 & 0.008 & - & - & - \\
$\vartheta$ & Beta & 0.70 & 0.05 & 0.174 & 0.208 & 0.243 & 0.157 & 0.186 & 0.215 \\
$h$ & Beta & 0.70 & 0.05 & 0.548 & 0.604 & 0.659 & 0.601 & 0.661 & 0.718 \\
$\delta^{\prime \prime} / \delta^{\prime}$ & Gam & 1.00 & 0.05 & 0.939 & 1.020 & 1.106 & 0.924 & 1.005 & 1.090 \\
\hline \hline
\end{tabular}

Note: ${ }^{*}$ Mean

Table 2: Model Comparison

\begin{tabular}{l|ll|c}
\hline \hline & \multicolumn{2}{|c|}{ Log marginal data density } & Posterior odds \\
& FA & no FA & \\
\hline \hline U.S. & 1880.2 & 1829.8 & $10^{21}$ \\
Euro Area & 1921.0 & 1881.1 & $10^{17}$ \\
\hline \hline
\end{tabular}

Note: Posterior odds of the hypothesis FA versus no FA 
Table 3: Prior and Posterior Distribution for the Euro Area

\begin{tabular}{l|ccc|ccc|ccc}
\hline \hline Parameter & \multicolumn{3}{|c|}{ Prior } & \multicolumn{3}{|c|}{ Financial Accelerator } & \multicolumn{3}{c}{ no Fin. Accelerator } \\
& Type & Mode & St. Er. & $5 \%$ & Mean & $95 \%$ & $5 \%$ & Mean & $95 \%$ \\
\hline \hline$\sigma_{r}$ & Gam & 0.01 & 0.005 & 0.002 & 0.002 & 0.003 & 0.002 & 0.003 & 0.003 \\
$\sigma_{a}$ & Gam & 0.01 & 0.005 & 0.007 & 0.008 & 0.009 & 0.007 & 0.008 & 0.009 \\
$\sigma_{g}$ & Gam & 0.01 & 0.005 & 0.015 & 0.017 & 0.019 & 0.014 & 0.016 & 0.018 \\
$\sigma_{\nu}$ & Gam & 0.10 & 0.05 & 0.082 & 0.155 & 0.218 & 0.053 & 0.104 & 0.181 \\
$\sigma_{\xi}$ & Gam & 0.10 & 0.05 & 0.027 & 0.032 & 0.037 & 0.027 & 0.033 & 0.041 \\
$\sigma_{\lambda}$ & Gam & 0.10 & 0.05 & 0.272 & 0.320 & 0.376 & 0.204 & 0.252 & 0.307 \\
$\sigma_{\tau}$ & Gam & 0.10 & 0.05 & 1.514 & 1.807 & 2.061 & 2.077 & 2.369 & 2.681 \\
$\rho^{r}$ & Beta & 0.85 & 0.10 & 0.428 & 0.499 & 0.564 & 0.309 & 0.395 & 0.479 \\
$\rho^{a}$ & Beta & 0.85 & 0.10 & 0.965 & 0.985 & 0.996 & 0.748 & 0.842 & 0.949 \\
$\rho^{g}$ & Beta & 0.85 & 0.10 & 0.739 & 0.841 & 0.948 & 0.934 & 0.965 & 0.987 \\
$\rho^{\nu}$ & Beta & 0.85 & 0.10 & 0.993 & 0.996 & 0.998 & 0.990 & 0.994 & 0.997 \\
$\rho^{\xi}$ & Beta & 0.85 & 0.10 & 0.99 & 0.995 & 0.999 & 0.988 & 0.994 & 0.998 \\
$\gamma^{\pi}$ & Norm & 1.50 & 0.05 & 1.482 & 1.556 & 1.631 & 1.477 & 1.568 & 1.651 \\
$\gamma^{y}$ & Norm & 0.50 & 0.05 & 0.146 & 0.227 & 0.307 & 0.057 & 0.152 & 0.245 \\
$\sigma$ & Norm & 1.00 & 0.10 & 1.052 & 1.211 & 1.373 & 0.943 & 1.093 & 1.247 \\
$\theta$ & Beta & 0.70 & 0.05 & 0.812 & 0.832 & 0.852 & 0.822 & 0.843 & 0.862 \\
$\varphi$ & Unif & $-0.5^{*}$ & 0.29 & -0.999 & -0.973 & -0.92 & -0.458 & -0.347 & -0.264 \\
$\gamma$ & Beta & .975 & 0.01 & 0.991 & 0.994 & 0.997 & 0.954 & 0.971 & 0.985 \\
$\mu$ & Beta & 0.12 & 0.05 & 0.117 & 0.182 & 0.245 & - & - & - \\
$r^{k}-r$ & Gam & 0.005 & 0.002 & 0.006 & 0.009 & 0.012 & - & - & - \\
$\vartheta$ & Beta & 0.70 & 0.05 & 0.236 & 0.274 & 0.311 & 0.210 & 0.245 & 0.279 \\
$h$ & Beta & 0.70 & 0.05 & 0.458 & 0.516 & 0.574 & 0.501 & 0.569 & 0.635 \\
$\delta^{\prime \prime} / \delta^{\prime}$ & Gam & 1.00 & 0.05 & 0.913 & 0.997 & 1.087 & 0.936 & 1.013 & 1.095 \\
\hline \hline
\end{tabular}

Note: * Mean 


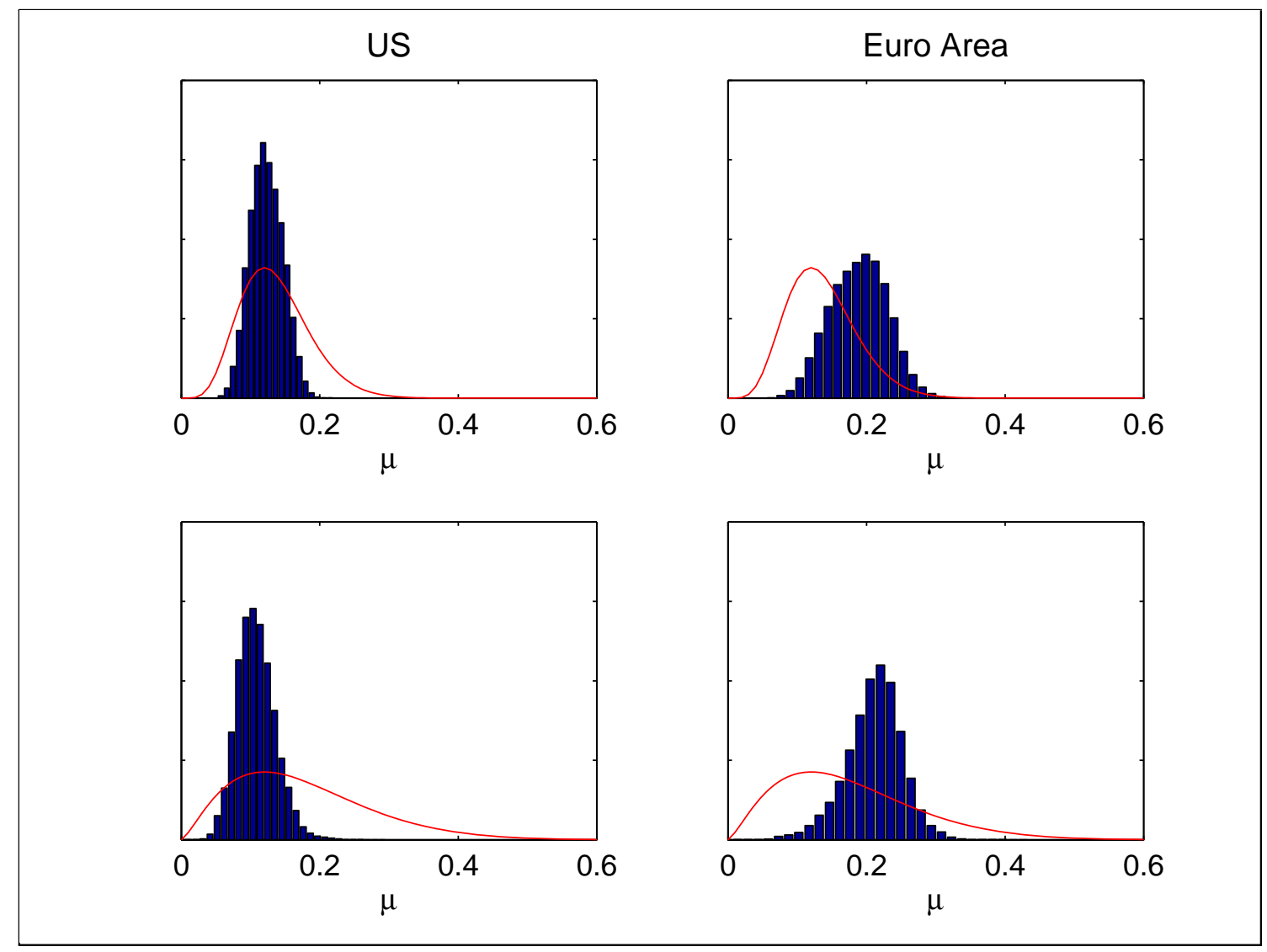

Figure 1: Prior and posterior distribution of $\mu$. The first row corresponds to a beta prior with mode 0.12 and standard deviation 0.05 . The second row corresponds to a beta prior with mode 0.12 and standard deviation 0.10 . 


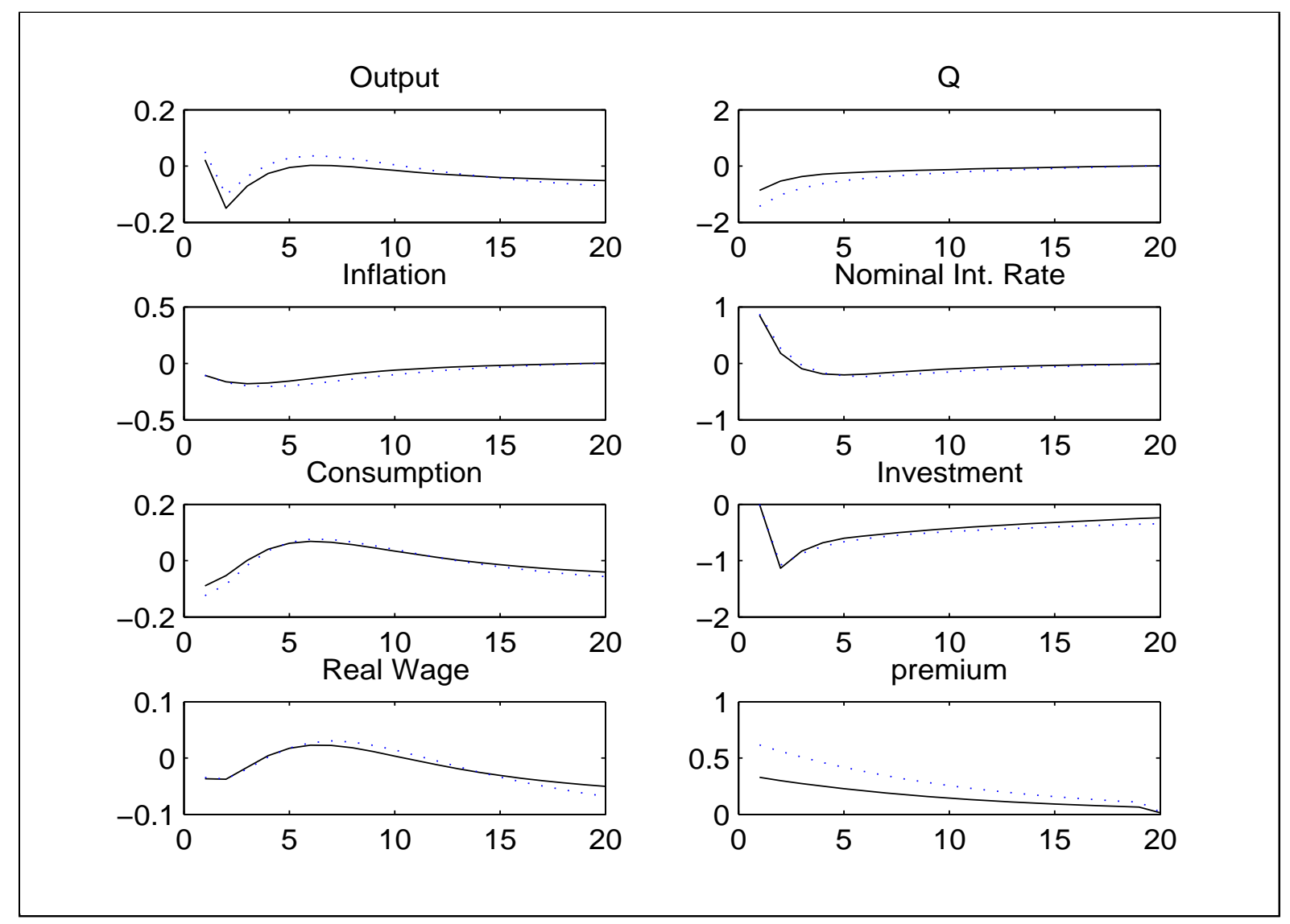

Figure 2: Impulse Response functions to a one percent shock to the nominal interest rate (annual) for the model with monitoring costs. Solid line: U.S. data. Doted line: European data. Values expressed as percentage deviation from steady state values, and in the case of inflation, the nominal interest rate and premium as annual percentage points. 

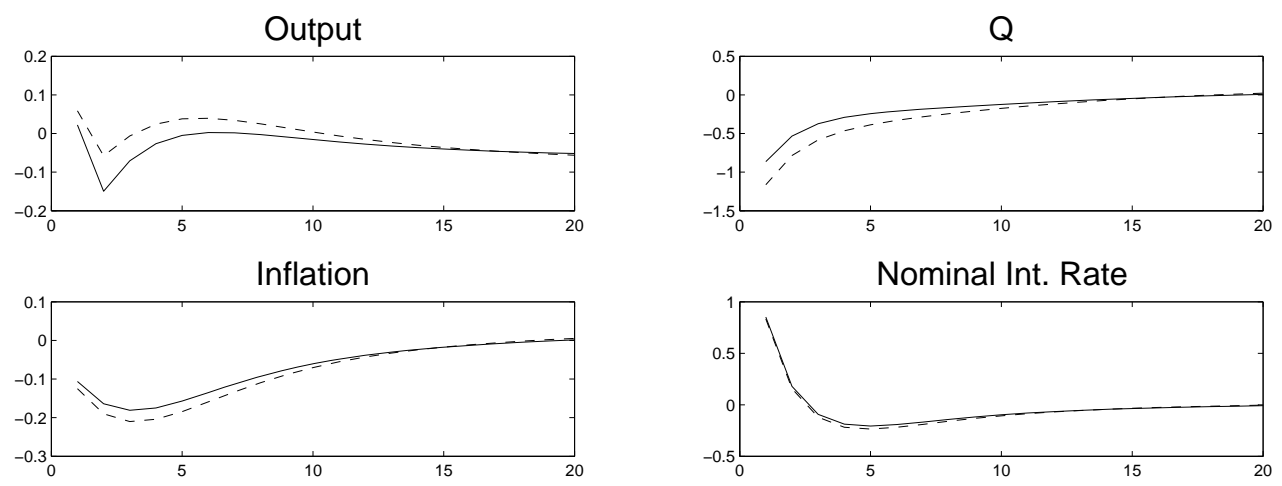

Nominal Int. Rate
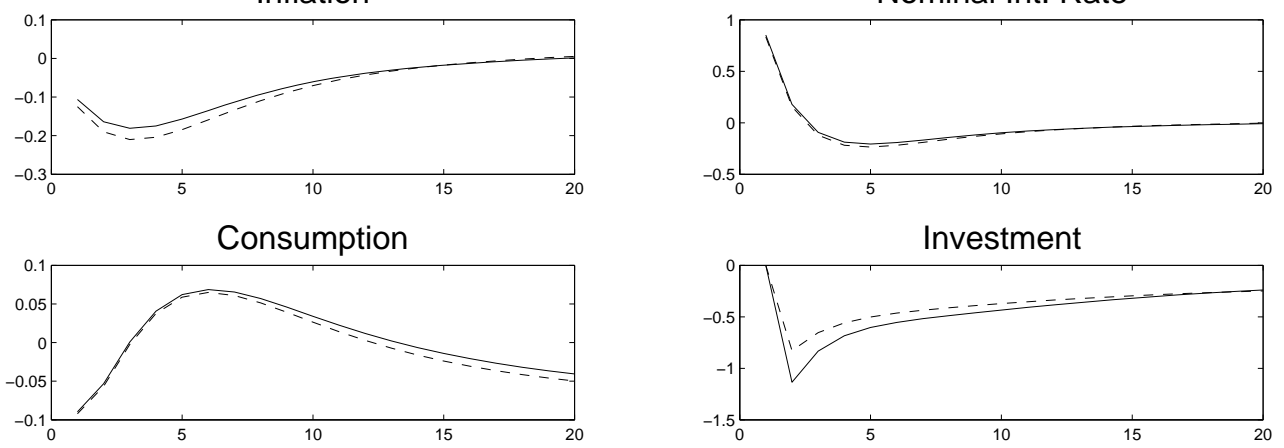

Real Wage
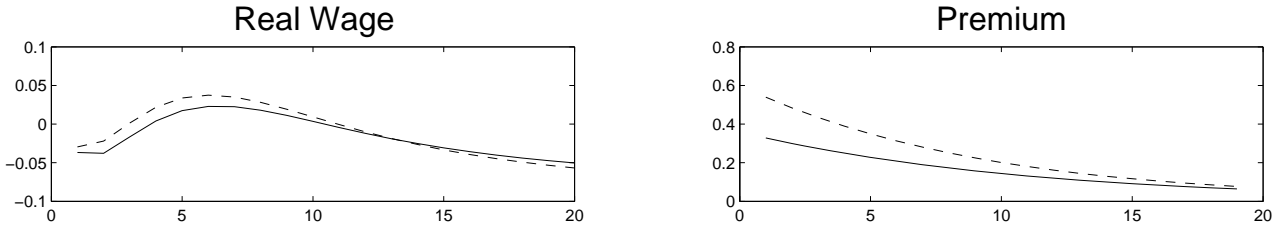

Figure 3: Counterfactual: Impulse Response functions to a one percent shock to the nominal interest rate (annual) for the model with monitoring costs. Solid line: U.S. data. Dashed line: U.S. data using credit market frictions and investment adjustment costs as in the Euro area. Values expressed as percentage deviation from steady state values, and in the case of inflation. the nominal interest rate and premium as annual percentage points. 

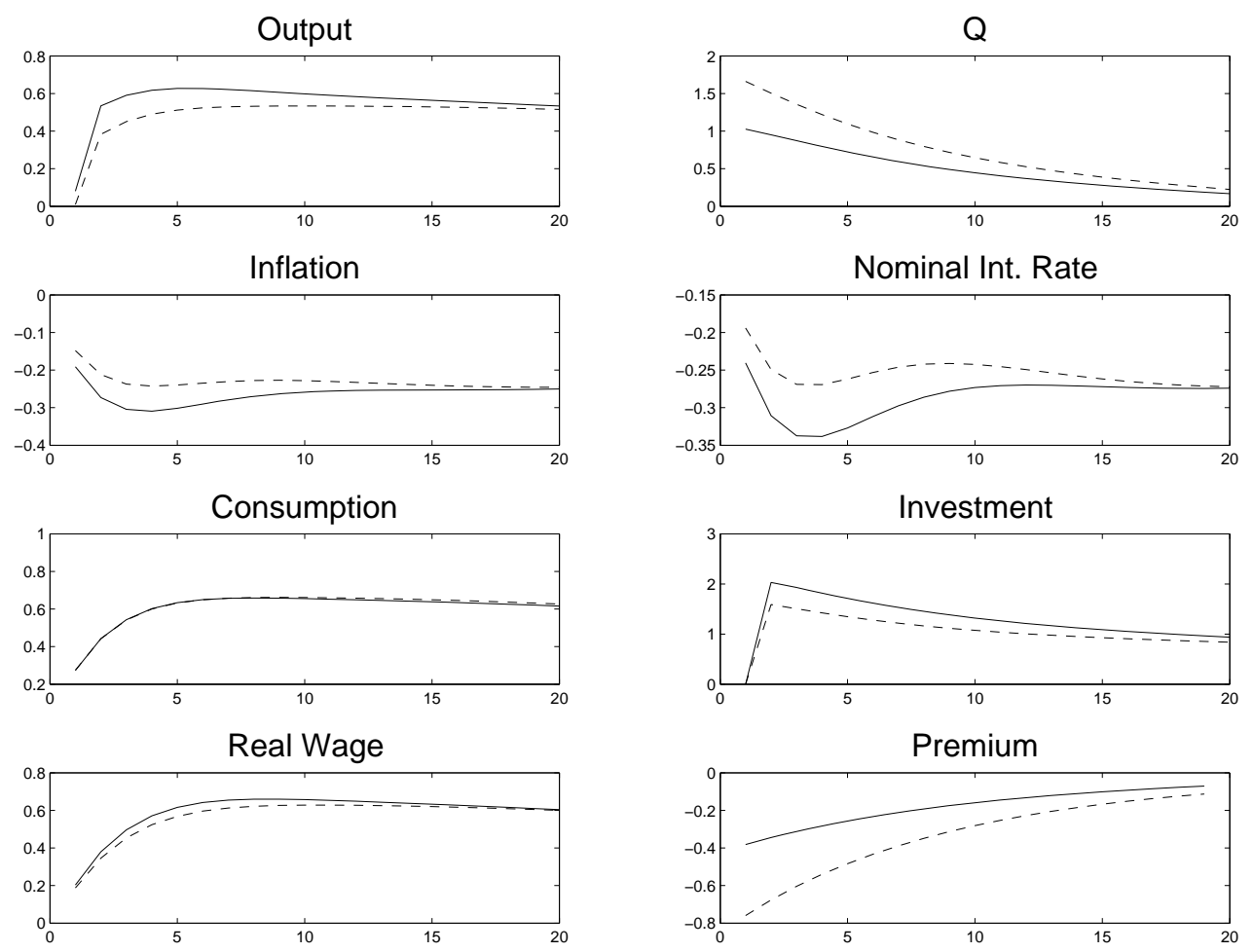

Figure 4: Counterfactual: Impulse Response functions to a one standard deviation shock to productivity for the model with monitoring costs. Solid line: U.S. data. Dashed line: U.S. data using credit market frictions and investment adjustment costs as in the Euro area. Values expressed as percentage deviation from steady state values, and in the case of inflation, the nominal interest rate and premium as annual percentage points. 

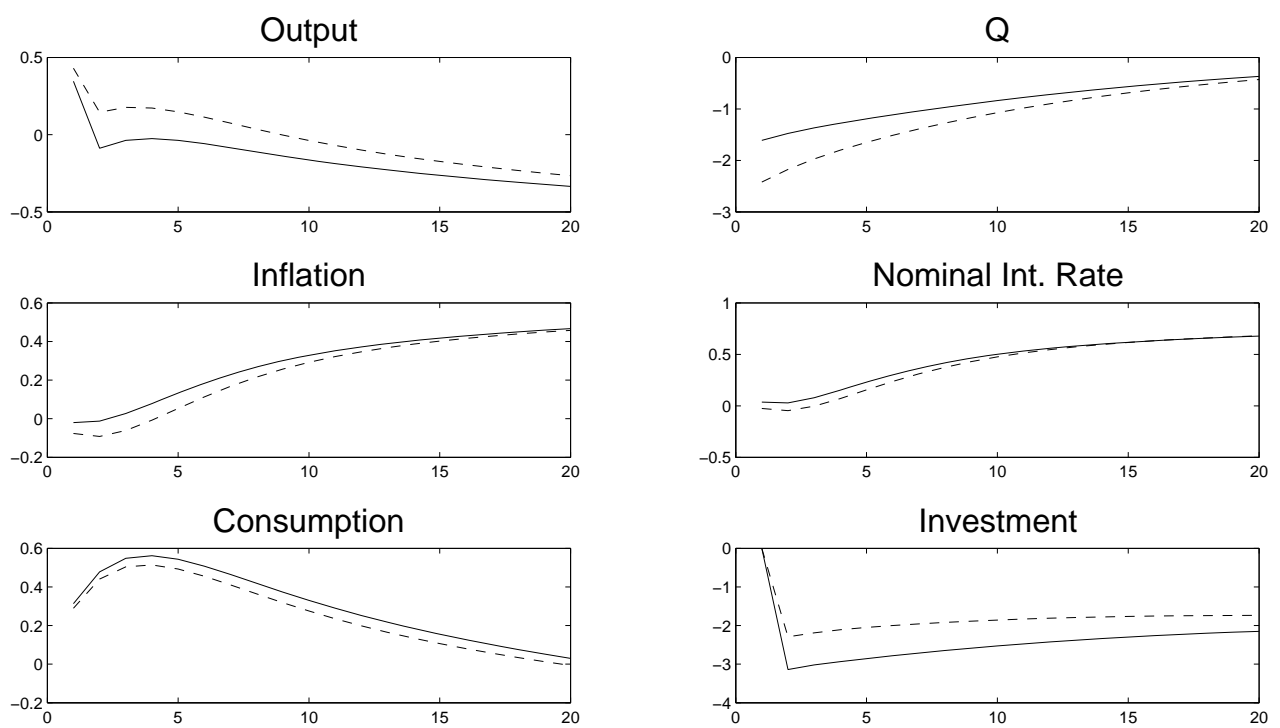

Investment
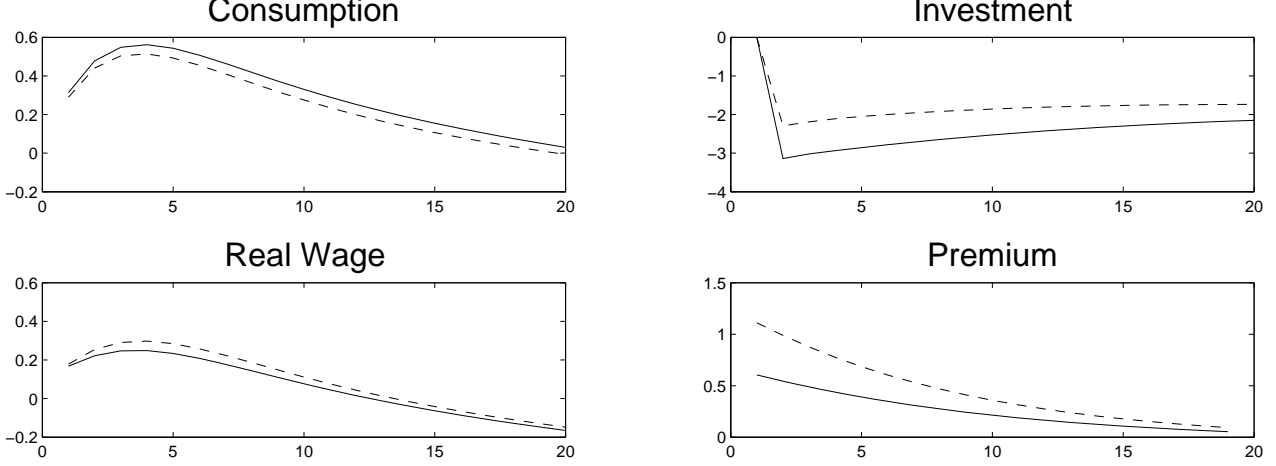

Figure 5: Counterfactual: Impulse Response functions to a one standard deviation preference shock for the model with monitoring costs. Solid line: U.S. data. Dashed line: U.S. data using credit market frictions and investment adjustment costs as in the Euro area. Values expressed as percentage deviation from steady state values, and in the case of inflation, the nominal interest rate and premium as annual percentage points. 


\section{Earlier Working Papers:}

For a complete list of Working Papers published by Sveriges Riksbank, see www.riksbank.se

Estimation of an Adaptive Stock Market Model with Heterogeneous Agents by Henrik Amilon ........ 2005:177

Some Further Evidence on Interest-Rate Smoothing: The Role of Measurement

Errors in the Output Gap by Mikael Apel and Per Jansson.....

Bayesian Estimation of an Open Economy DSGE Model with Incomplete Pass-Through

by Malin Adolfson, Stefan Laséen, Jesper Lindé and Mattias Villani

Are Constant Interest Rate Forecasts Modest Interventions? Evidence from

an Estimated Open Economy DSGE Model of the Euro Area by Malin Adolfson,

Stefan Laséen, Jesper Lindé and Mattias Villani

Inference in Vector Autoregressive Models with an Informative

Prior on the Steady State by Mattias Villani

Bank Mergers, Competition and Liquidity by Elena Carletti, Philipp Hartmann

and Giancarlo Spagnolo

Testing Near-Rationality using Detailed Survey Data

by Michael F. Bryan and Stefan Palmqvist.

Exploring Interactions between Real Activity and the Financial Stance

by Tor Jacobson, Jesper Lindé and Kasper Roszbach

Two-Sided Network Effects, Bank Interchange Fees,

and the Allocation of Fixed Costs by Mats A. Bergman .....

Trade Deficits in the Baltic States: How Long Will the Party Last?

by Rudolfs Bems and Kristian Jönsson.

Real Exchange Rate and Consumption Fluctuations follwing Trade Liberalization

by Kristian Jönsson

Modern Forecasting Models in Action: Improving Macroeconomic Analyses at Central Banks

by Malin Adolfson, Michael K. Andersson, Jesper Lindé, Mattias Villani and Anders Vredin.....

Bayesian Inference of General Linear Restrictions on the Cointegration Space by Mattias Villani.

2005:189

Forecasting Performance of an Open Economy Dynamic Stochastic General Equilibrium Model

by Malin Adolfson, Stefan Laséen, Jesper Lindé and Mattias Villani

Forecast Combination and Model Averaging using Predictive Measures

by Jana Eklund and Sune Karlsson.

Swedish Intervention and the Krona Float, 1993-2002

by Owen F. Humpage and Javiera Ragnartz

A Simultaneous Model of the Swedish Krona, the US Dollar and the Euro

by Hans Lindblad and Peter Sellin

Testing Theories of Job Creation: Does Supply Create Its Own Demand?

by Mikael Carlsson, Stefan Eriksson and Nils Gottfries.....

Down or Out: Assessing The Welfare Costs of Household Investment Mistakes

by Laurent E. Calvet, John Y. Campbell and Paolo Sodini

Efficient Bayesian Inference for Multiple Change-Point and Mixture Innovation Models

by Paolo Giordani and Robert Kohn

Derivation and Estimation of a New Keynesian Phillips Curve in a Small Open Economy

by Karolina Holmberg

Technology Shocks and the Labour-Input Response: Evidence from Firm-Level Data

by Mikael Carlsson and Jon Smedsaas

Monetary Policy and Staggered Wage Bargaining when Prices are Sticky

by Mikael Carlsson and Andreas Westermark

The Swedish External Position and the Krona by Philip R. Lane

Price Setting Transactions and the Role of Denominating Currency in FX Markets

by Richard Friberg and Fredrik Wilander.....

The geography of asset holdings: Evidence from Sweden

by Nicolas Coeurdacier and Philippe Martin

Evaluating An Estimated New Keynesian Small Open Economy Model

by Malin Adolfson, Stefan Laséen, Jesper Lindé and Mattias Villani .......

The Use of Cash and the Size of the Shadow Economy in Sweden

by Gabriela Guibourg and Björn Segendorf

Bank supervision Russian style: Evidence of conflicts between micro- and macro-

prudential concerns by Sophie Claeys and Koen Schoors 
Optimal Monetary Policy under Downward Nominal Wage Rigidity

by Mikael Carlsson and Andreas Westermark....

Financial Structure, Managerial Compensation and Monitoring

by Vittoria Cerasi and Sonja Daltung

Financial Frictions, Investment and Tobin's q by Guido Lorenzoni and Karl Walentin

2007:208

Sticky Information vs. Sticky Prices: A Horse Race in a DSGE Framework

by Mathias Trabandt

Acquisition versus greenfield: The impact of the mode of foreign bank entry

on information and bank lending rates by Sophie Claeys and Christa Hainz

Nonparametric Regression Density Estimation Using Smoothly Varying Normal Mixtures

by Mattias Villani, Robert Kohn and Paolo Giordani

The Costs of Paying - Private and Social Costs of Cash and Card

by Mats Bergman, Gabriella Guibourg and Biörn Segendorf

Using a New Open Economy Macroeconomics model to make real nominal exchange rate forecasts by Peter Sellin

Introducing Financial Frictions and Unemployment into a Small Open Economy Model

by Lawrence J. Christiano, Mathias Trabandt and Karl Walentin.....

Earnings Inequality and the Equity Premium by Karl Walentin

Bayesian forecast combination for VAR models by Michael $K$ Andersson and Sune Karlsson

2007:216

Do Central Banks React to House Prices?

by Daria Finocchiaro and Virginia Queijo von Heideken.

2007:217

The Riksbank's Forecasting Performance

by Michael K. Andersson, Gustav Karlsson and Josef Svensson

Macroeconomic Impact on Expected Default Freqency

by Per Åsberg and Hovick Shahnazarian

Monetary Policy Regimes and the Volatility of Long-Term Interest Rates

by Virginia Queijo von Heideken

Governing the Governors: A Clinical Study of Central Banks

by Lars Frisell, Kasper Roszbach and Giancarlo Spagnolo

The Monetary Policy Decision-Making Process and the Term Structure of Interest Rates

by Hans Dillén 
Website: www.riksbank.se 